\title{
ANALISIS POTENSI DAN PEMETAAN SEKTOR EKONOMI KREATIF SUBSEKTOR KULINER TERHADAP PENDAPATAN ASLI DAERAH DI KOTA SAMARINDA
}

\section{(POTENTIAL AND MAPPING ANALYSIS OF CULINARY SUBSECTOR CREATIVE ECONOMIC SECTORS ON LOCAL GOVERNMENT REVENUE IN SAMARINDA CITY)}

\author{
Bramantyo Adi Nugroho \\ Badan Penelitian dan Pengembangan Daerah Provinsi Kalimantan Timur \\ Jalan M.T. Haryono No. 126 Samarinda \\ Email : bramantyo@kaltimprov.go.id
}

Diterima: 25 November 2021; Direvisi: 3 Desember 2021; Disetujui: 30 Desember 2021

\begin{abstract}
The purpose of this study is to identify the potential of the creative economy sector of the culinary sub-sector in Samarinda City and identify characteristics and creativity by mapping the creative economy sector of the culinary sub-sector in Samarinda City. In this study using a mixed method, namely the Concurrent Embedded Model Combination Method. The location of this study is in 10 sub-districts in Samarinda City with a total sample of 303 respondents. Based on the analysis, it can be concluded that the scope of the creative economy sector in the culinary sub-sector that is mostly found in Samarinda City is food stalls, depots, restaurants and cafes. The character of the creative economy sector activists in the culinary sub-sector in Samarinda City is approximately 38 years old, the majority of whom have undergraduate education (S1). The creative economy sector in the culinary sub-sector in Samarinda City has not fully fulfilled all the elements of creativity. Of the five elements of creativity, only the involvement of professional cooks and the use of technology are above 50 percent. According to the SCP method, the structure of the creative economy of the culinary sub-sector in Samarinda City can be seen from the elements of the business units that are still independent. Conduct in this sub-sector can be seen from the element of price determination, the majority of which are self-pricing without looking at price information from competitors/other culinary activists. In addition, the marketing methods used by culinary activists still use Social Media, Online Applications and Mouth to Mouth. Performance in this sub-sector can be seen from the elements of turnover and workforce, the majority of which are still small-scale businesses. Based on the calculation model for the potential restaurant tax in Samarinda City, it can be concluded that each additional one taxpayer in the culinary sub-sector will increase the realization of the Samarinda City restaurant tax by an average of Rp. 15,686,485.00 ceteris paribus assumption.
\end{abstract}

Keywords: Culinary; Creative Economy; Restaurant tax.

\begin{abstract}
ABSTRAK
Tujuan dari kajian ini adalah untuk mengidentifikasi potensi sektor ekonomi kreatif subsektor kuliner di Kota Samarinda dan mengidentifikasi karakteristik dan kreatifitas dengan cara melakukan pemetaan ekonomi kreatif subsektor kuliner di Kota Samarinda. Dalam kajian ini menggunakan metode campuran yaitu Metode Kombinasi Metode Campuran Tidak Berimbang (Concurrent Embedded Method). Lokasi kajian ini di 10 Kecamatan di Kota Samarinda dengan jumlah sampel sebanyak 303 responden. Berdasarkan analisis diperoleh kesimpulan ruang lingkup sektor ekonomi kreatif subsektor kuliner yang terbanyak ditemukan di Kota Samarinda adalah warung makan, depot, restoran dan kafe. Adapun karakter penggiat sector ekonomi kreatif subsektor kuliner di Kota Samarinda kurang lebih berusia 38 tahun, mayoritas berpendidikan sarjana (S1). Sektor ekonomi kreatif subsektor kuliner di Kota Samarinda belum secara keseluruhan memenuhi semua unsur
\end{abstract}




\begin{abstract}
kreatifitas. Dari lima unsur kreatifitas hanya unsur keterlibatan juru masak profesional dan unsur penggunaan teknologi yang persentasenya diatas 50 persen. Menurut metode SCP, Structure pada ekonomi kreatif subsektor kuliner di Kota Samarinda terlihat dari unsur unit usahanya masih bersifat independent. Conduct pada subsektor ini, terlihat dari unsur penentuan harga yang mayoritas menetapkan sendiri harga (self-pricing) tanpa melihat informasi harga pada pesaing/penggiat kuliner lainnya. Selain itu metode pemasaran yang digunakan para penggiat kuliner masih menggunakan Media Sosial, Aplikasi Online dan Mulut ke Mulut (Mouth to Mouth). Performance pada subsektor ini terlihat dari unsur omset dan tenaga kerja yang mayoritas masih berskala usaha kecil. Berdasarkan model perhitungan potensi pajak restoran di Kota Samarinda, diperoleh kesimpulan bahwa setiap bertambahnya satu wajib pajak subsektor kuliner akan meningkatkan realisasi pajak restoran Kota Samarinda sebesar rata-rata Rp15.686.485,00 asumsi ceteris paribus.
\end{abstract}

Kata Kunci : Kuliner; Ekonomi Kreatif; Pajak Restoran.

\title{
PENDAHULUAN
}

Kalimat "Ekonomi Kreatif" diutarakan oleh John Howkins dalam bukunya "The Creative Economy: How People Make Money from Ideas" (2001). Hal ini dilatarbelakangi oleh Howkins yang menyadari adanya embrio ekonomi baru berbasis kreativitas. Hal tersebut terlihat pada Amerika Serikat yang pada tahun 1997 menghasilkan produk-produk Hak Kekayaan Intelektual (HKI) mencapai senilai 414 Miliar US Dollar. Hal ini membuat HKI ekspor nomor satu Amerika Serikat. Dalam hal ini, Howkins dengan ringkas mendefinisikan Ekonomi Kreatif, yaitu "The creation of value as a result of idea".

Ekonomi Kreatif menurut Cetak Biru Pengembangan Ekonomi Kreatif Nasional 20092015 (2008) didefinisikan sebagai "Era baru ekonomi pascaekonomi pertanian, ekonomi industri, dan ekonomi informasi, yang mengintensifkan informasi dan kreativitas dengan mengandalkan ide dan pengetahuan dari sumber daya manusia sebagai faktor produksi utama dalam kegiatan ekonominya".

Adapun definisi Industri Kreatif di Indonesia seperti yang tertulis dalam Cetak Biru Pengembangan Ekonomi Kreatif Nasional 2009-2015 (2008) adalah "Industri yang berasal dari pemanfaatan kreativitas, keterampilan serta bakat individu untuk menciptakan kesejahteraan serta lapangan pekerjaan melalui penciptaan dan pemanfaatan daya kreasi dan daya cipta individu tersebut". Jadi dapat disimpulkan bahwa Ekonomi Kreatif dalam hubungannya dengan Industri Kreatif adalah kegiatan ekonomi yang mencakup industri dengan kreativitas sumber daya manusia sebagai aset utama untuk menciptakan nilai tambah ekonomi

Adapun Ekonomi Kreatif meliputi 16 subsektor yaitu (1) Aplikasi dan Pengembang Permainan; (2) Arsitektur; (3) Desain Interior; (4) Desain Komunikasi Visual; (5) Desain Produk; (6) Fashion; (7) Film, Animasi dan Video; (8) Fotografi; (9) Kriya; (10) Kuliner; (11) Musik; (12) Penerbitan; (13) Periklanan; (14) Seni Pertunjukan; (15) Seni Rupa; dan (16) Televisi dan Radio.

Badan Pusat Statistik berdasarkan hasil survei Ekonomi Kreatif mampu memberikan kontribusi secara signifikan terhadap pertumbuhan ekonomi nasional. Pada tahun 2015, sektor ini menyumbangkan 852 triliun rupiah terhadap PDB nasional (7,38 persen) dan menyerap 15,9 juta tenaga kerja (13,9 persen) serta nilai ekspor sebesar US\$19,4 miliar (12,88 persen). Pada tahun 2016 terdapat peningkatan kontribusi Ekonomi Kreatif yang signifikan terhadap perekonomian nasional dari tahun 2010-2015 yaitu sebesar 10,14 persen per tahun. Hal ini membuktikan bahwa Ekonomi Kreatif memiliki potensi untuk berkembang di masa mendatang. Sedangkan subsektor pada ekonomi kreatif di Indonesia didominasi tiga subsektor yaitu kuliner (41,6 persen), fashion (18,15 persen), dan kriya (15,70 persen). Kuliner terdiri dari restoran, warung, penyediaan makanan keliling, kedai, jasa boga dan lain sebagainya.

Pada tahun 2014, Mellita melakukan kajian Pemetaan Industri Kreatif Dalam Meningkatkan Pertumbuhan Ekonomi Kawasan Urban Di Kota Palembang. Dalam kajian ini dilakukan pemetaan terhadap industri kreatif di Kota Palembang disertai dengan tinjauan 
terhadap nilai PDRB dan ketenagakerjaan. Dalam kajian tersebut belum dilakukan pemetaan secara spesifik terhadap subsektor industri kreatif dan sumbangsihnya terhadap Pendapatan Asli Daerah (PAD).

Ekonomi kreatif juga merupakan salah satu penopang perekonomian di Provinsi Kalimantan Timur walaupun dengan jumlah yang tidak besar karena provinsi ini masih mengandalkan sumber daya alam sebagai penopang perekonomiannya. Salah satu kota di Provinsi Kalimantan Timur dengan perkembangan ekonomi kreatif cukup pesat adalah Kota Samarinda dengan subsektor kuliner. Sampai saat ini belum diketahui secara pasti jumlah penggiat sektor ekonomi kreatif subsektor kuliner baik di Kota Samarinda baik dari unsur jumlah, karakteristiknya, namun potensinya sangat besar.

Tabel 1.

Data Realisasi Pajak Restoran Tahun 2015-2018

\begin{tabular}{ccc}
\hline Tahun & $\begin{array}{c}\text { Realisasi Pajak } \\
\text { Restoran }\end{array}$ & $\begin{array}{c}\text { Persentase } \\
\text { Kenaikan (\%) }\end{array}$ \\
\hline 2015 & $34.178 .845 .016,61$ & - \\
2016 & $40.476 .009 .169,05$ & 18,42 \\
2017 & $44.947 .506 .757,27$ & 11,05 \\
2018 & 57.135 .686 .655 & 27,12 \\
\hline Sumber: Badan Pendapatan Kota Samarinda (diolah)
\end{tabular}

Berdasarkan tabel 1, menurut data dari Badan Pendapatan Daerah Kota Samarinda, Pajak Restoran (PB1) pada tahun 2015 yang berhasil diperoleh sebesar 34,18 Milyar Rupiah. Pada tahun 2016 sebesar 40,48 Milyar Rupiah naik sebesar 18,42 persen dari tahun sebelumnya. Pada tahun 2017 sebesar 44,95 Milyar Rupiah naik sebesar 11,05 persen dari tahun sebelumnya. Sedangkan pada tahun 2018 sebesar 57,14 Milyar Rupiah naik sebesar 27,12 persen dari tahun sebelumnya. Berdasarkan data tersebut, potensi kuliner di Kota Samarinda cukup besar dan terus mengalami kenaikan setiap tahunnya. Selain itu, dapat terlihat dari event-event ekonomi kreatif yang diselenggarakan di kota Samarinda, subsektor kuliner selalu mengisi acara tersebut dengan jumlah stand yang paling banyak dibandingkan dengan subsektor ekonomi kreatif lainnya.

Adapun maksud dan tujuan dari kegiatan ini adalah (1) Melakukan identifikasi karakteristik dan kreatifitas dengan cara melakukan pemetaan sektor ekonomi kreatif subsektor kuliner di Kota Samarinda dan (2) Melakukan identifikasi potensi sektor ekonomi kreatif subsektor kuliner di Kota Samarinda terhadap Pendapatan Asli Daerah Kota Samarinda. Sedangkan ruang lingkup dari kegiatan ini adalah terbatas pada potensi dan pemetaan sektor ekonomi kreatif subsektor kuliner terhadap pendapatan asli daerah di Kota Samarinda.

\section{METODE}

Dalam kajian ini menggunakan metode campuran yaitu Concurrent Embedded Methode (Metode Campuran Tidak Berimbang). Metode ini merupakan kombinasi antara metode penelitian kualitatif dan kuantitatif dengan cara mencampur kedua metode tersebut secara tidak seimbang. Metode kajian ini mengumpulkan data (kualitatif dan kuantitatif) secara simultan dalam satu tahap pengumpulan data sehingga data yang diperoleh menjadi lengkap dan lebih akurat. Lokasi kajian ini meliputi 10 Kecamatan di Kota Samarinda,

Kajian ini menggunakan teknik simple random sampling. Teknik tersebut merupakan teknik pengambilan sampel dari anggota populasi yang dilakukan secara acak tanpa memperhatikan strata yang ada dalam populasi itu (Sugiyono (2001:57). Sedangkan menurut Kerlinger (2006:188), simple random sampling adalah metode penarikan dari sebuah populasi atau semesta dengan cara tertentu sehingga setiap anggota populasi atau semesta memiliki peluang yang sama untuk terpilih atau terambil. 
Jumlah sampel untuk satu Kota Samarinda yang akan diambil pada penelitian ini didapat dengan menggunakan rumus/ ketentuan dari Slovin (Umar 1997:107-108), yaitu:

$$
n=\frac{N}{1+N(e)^{2}}
$$

\author{
Keterangan: \\ $\mathrm{n}=$ jumlah sampel \\ $\mathrm{N}=$ jumlah populasi \\ $\mathrm{e}=$ margin error (tingkat kesalahan)
}

Teknik pengumpulan data lain digunakan adalah In-Depth Interview (Wawancara Mendalam) dan dokumentasi. Moleong (2005) menyebutkan wawancara adalah percakapan dengan maksud tertentu yang dilakukan oleh dua pihak yaitu pewawancara yang mengajukan pertanyaan dan terwawancara yang memberikan jawaban atas pertanyaan tersebut.

Dalam kajian ini, peneliti menggunakan model analisis data interaktif menurut Miles dan Huberman. Model analisis data ini memiliki 4 tahapan, yaitu tahap pertama pengumpulan data menggunakan kuesioner, tahap kedua reduksi data, tahap ketiga display data, dan tahap keempat penarikan kesimpulan serta verifikasi data.

Metode analisis yang digunakan pada kajian ini yaitu analisis deskriptif dengan pendekatan Structure Conduct-Performance (SCP). Struktur (structure) suatu industri akan menentukan bagaimana perilaku para penggiat industri (conduct) yang pada akhirnya menentukan kinerja (performance) industri tersebut dalam hal ini kuliner yang ada di Kota Kota Samarinda. Berikutnya digunakan analisis regresi linear sederhana untuk menghitung potensi pajak restoran di Kota Samarinda. Dengan menggunakan program komputerisasi yaitu program SPSS. Persamaan umum regresi linear sederhana adalah sebagai berikut:

$$
\mathrm{Y}=\alpha+\beta \mathrm{X}
$$

$$
\begin{aligned}
& \text { Dimana: } \\
& \begin{aligned}
Y & =\text { Variabel Dependen (Nilai Realisasi Pajak Restoran) } \\
\alpha & =\text { Nilai konstanta } \\
\beta & =\text { Koefisien regresi } \\
X & =\text { Variabel Independen (Jumlah Wajib Pajak Restoran) }
\end{aligned}
\end{aligned}
$$

Setelah dilakukan regresi, maka dilakukan beberapa uji agar dihasilkan estimasi/model yang terbaik, yaitu a) Uji Asumsi Klasik (Uji asumsi klasik pada kajian ini bertujuan untuk memperoleh model regresi yang menghasilkan estimator linier tidak bias yang terbaik (Best Linier Unbiased Estimator/BLUE). Uji asumsi klasik yang dilakukan yaitu menggunakan Uji Normalitas, Uji Autokorelasi, Uji Heterokedastisitas); Uji Regresi Linear Sederhana (Untuk uji nilai regeresinya sendiri menggunakan Uji t dan Uji korelasi/determinasi).

Adapun Definisi operasional pada persamaan regresi linier berganda penelitian ini adalah a) Realisasi Pajak Restotan (Y) adalah jumlah keseluruhan nilai realisasi Pajak Restoran antara Bulan Januari 2015 hingga Bulan Desember Tahun 2018 di Kota Samarinda; b) Jumlah wajib pajak (X) Adalah jumlah wajib pajak yang melakukan pembayaran pajak restoran antara Bulan Januari tahun 2015 hingga Bulan Desember tahun 2018 di Kota Samarinda. 


\section{HASIL DAN PEMBAHASAN}

Pada bagian ini akan dibahas mengenai pemetaan karakteristik dan potensi sektor ekonomi kreatif subsektor kuliner di Kota Samarinda. Adapun hasil Analisa data pada kedua kota tersebut adalah sebagai berikut:

\section{Karakteristik Sektor Ekonomi Kreatif Subsektor Kuliner di Kota Samarinda}

Pada bagian ini akan dibahas mengenai pemetaan sektor ekonomi kreatif subsektor kuliner Kota Samarinda meliputi sisi karakteristik, sisi kreativitas dan struktur-perilaku-kinerja (structure-conduct-performance).

Penentuan sampel menggunakan data dari Jumlah penggiat usaha kuliner yang terdata di Badan Pendapatan Daerah Kota Samarinda pada tahun 2018 sebanyak 1247. Adapun teknik pengambilan sampel dalam kajian ini menggunakan teknik simple random sampling dan perhitungan keseluruhan sampel diperoleh dari rumus slovin: $\mathbf{n}=\mathbf{N} /\left(\mathbf{1}+\mathbf{N e}^{\mathbf{2}}\right)$. Dimana $n$ adalah total sampel, $\mathrm{N}$ adalah jumlah populasi dan e pada tingkat 5 persen. Berdasarkan kriteria tersebut didapatkan total sampel sebanyak 303 responden.

Kota Samarinda merupakan daerah perkotaan dengan ruang lingkup sektor ekonomi kreatif subsektor kuliner mayoritas di kota ini adalah warung makan, depot, restoran dan kafe. Adapun alasan yang diinfokan oleh para responden yang berkecimpung pada subsektor kuliner antara lain berturut-turut disebabkan oleh (1) keahlian dalam mengolah makanan/minuman, (2) prospek usaha bagus, (3) hobi, (4) belum ada usaha sejenis di wilayah sekitar mereka berjualan, dan (5) permintaan konsumen.

Usia para penggiat ekonomi kreatif subsektor kuliner di Kota Samarinda rata-rata berusia 36-45 tahun. Hal ini menjadi indikasi bahwa penggiat subsektor kuliner pada rentang usia tersebut mampu meningkatkan potensi kreativitas dan inovasi yang dimiliki sampai ke taraf maksimal. Pada rentang usia ini pula, para penggiat berada dalam masa usia produktif dan mulai stabil dalam memutuskan kreativitas dan inovasi usaha yang akan diimplementasikan dalam usahanya, sesuai dengan pendapat (Lin, 2002) bahwa puncak kreativitas dan inovasi manusia terjadi dalam waktu 10 tahun dari sekitar umur 32 tahun. Usia penggiat kuliner di Kota Samarinda tersaji pada gambar 1 di bawah ini.

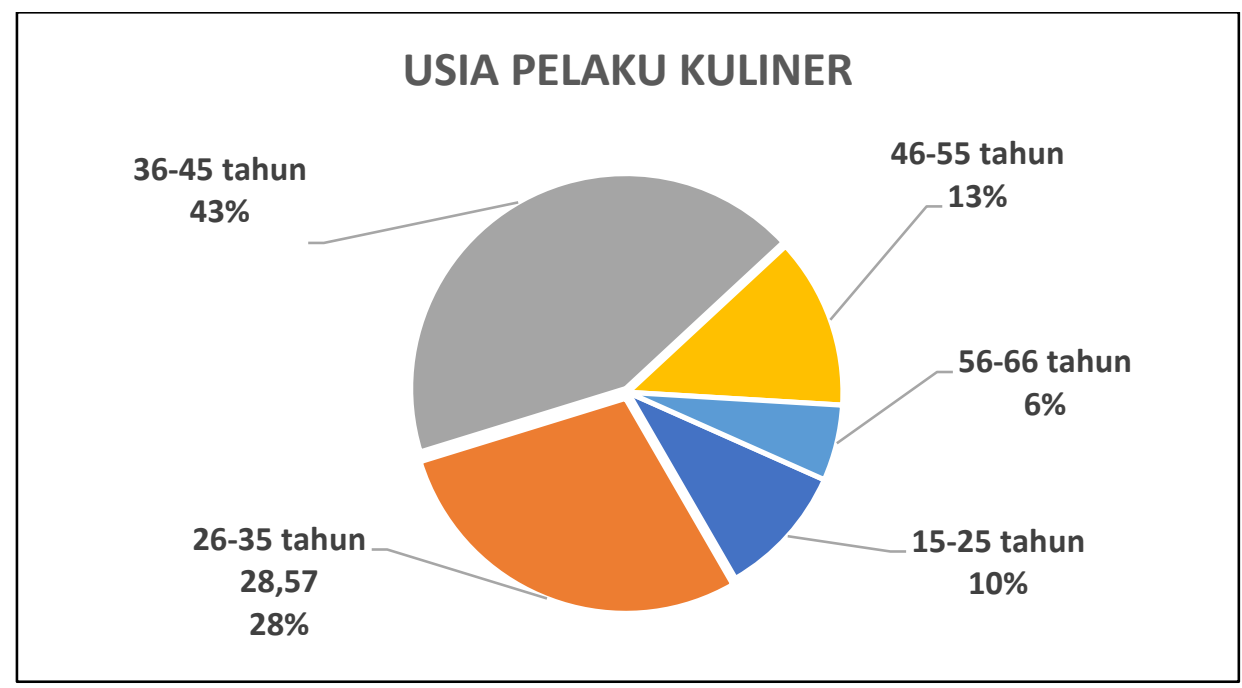

Gambar 1.

Usia Penggiat Sektor Ekonomi Kreatif Subsektor Kuliner

di Kota Samarinda Tahun 2019

Sumber: Hasil Survei (2019) 
Karakteristik penggiat sektor ekonomi kreatif subsektor kuliner berdasarkan tingkat pendidikan dapat terlihat pada Gambar 2. Sebanyak 52,86 persen dari total responden penggiat kuliner berpendidikan terakhir sarjana (S1). Dalam hal ini, tingkat pendidikan memiliki peran dalam membentuk kemampuan dalam pembelajaran ataupun penyerapan teknologi modern dan untuk mengembangkan kapasitas sehingga meningkatkan pembangunan ekonomi wilayah tersebut (Todaro, M.P., \& Smith, 2006).

Sesuai dengan teori human capital menyebutkan bahwa investasi dalam pekerjaan melalui pendidikan, pengalaman, keahlian dan pelatihan-pelatihan akan dihargai dalam lingkungan atau tempat kerja dan akan mendapatkan pekerjaan yang lebih baik (Hennekam \& Bennett, 2017). Oleh karena itu, untuk survive ataupun menjadi unggulan disubsektor ini para penggiat subsektor kuliner dapat meningkatkan keahliannya dengan cara belajar dan banyak mencari pengalaman kepada penggiat kuliner lain yang telah sukses serta mengikuti pelatihan-pelatihan.

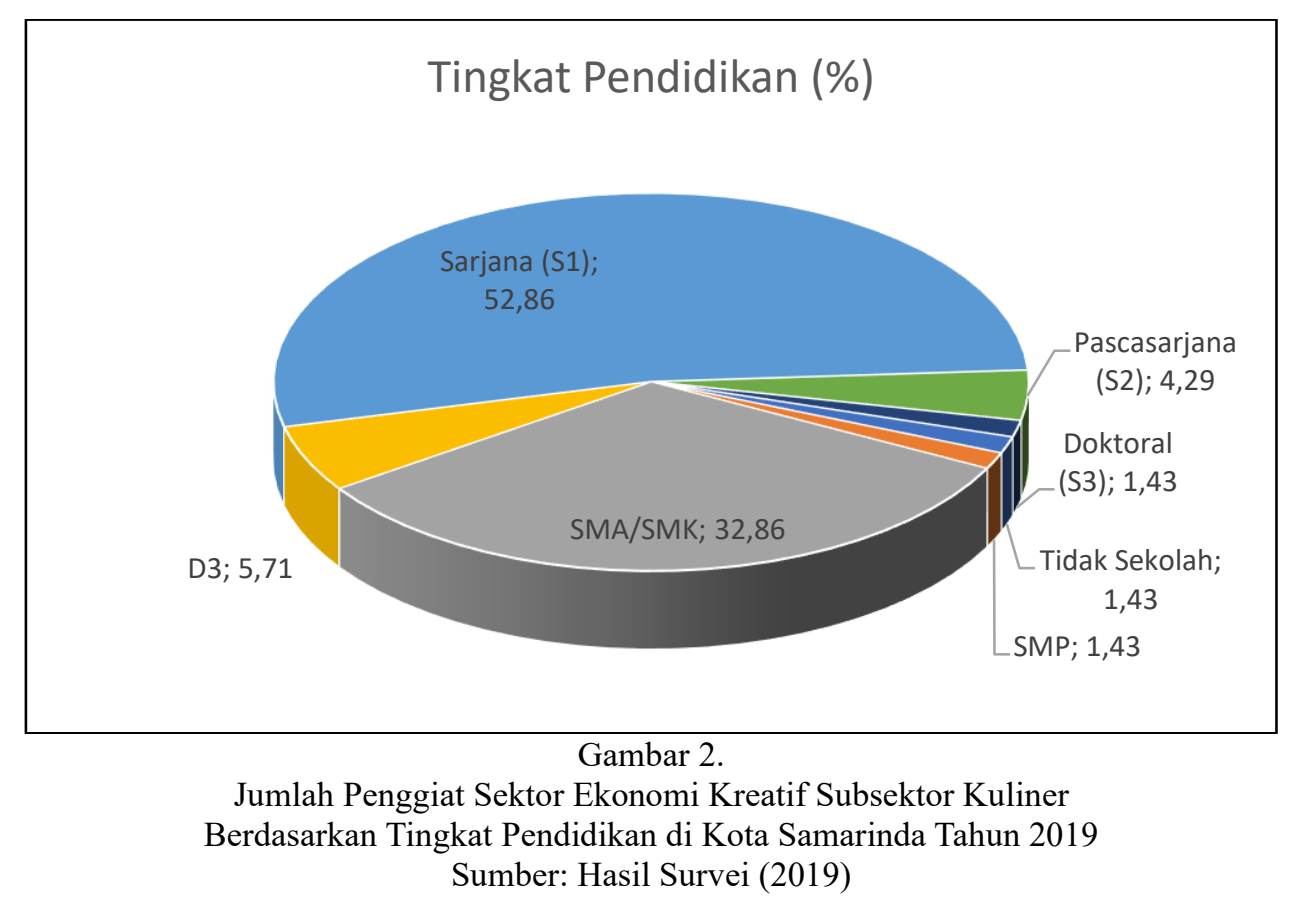

Pada tabel 2 memperlihatkan bahwa sektor ekonomi kreatif subsektor kuliner di Kota Samarinda belum secara penuh/mutlak memenuhi semua unsur kreativitas. Dari lima unsur kreativitas hanya 2 unsur kreativitas yang terpenuhi karena telah lebih dari 50 persen. Sisi tersebut adalah sisi keterlibatan juru masak profesional dan sisi penggunaan teknologi. Sedangkan ketiga sisi lainnya menjadi catatan bagi subsektor kuliner di Kota Samarinda. Ketiga sisi lain persentasenya masih di bawah 50 persen sehingga harus ditingkatkan agar dapat tumbuh dan bersaing kedepannya.

Tabel 2.

Kreativitas Subsektor Kuliner di Kota Samarinda Tahun 2019 (persen)

\begin{tabular}{clcc}
\hline No. & \multicolumn{1}{c}{ Kreatifitas Kuliner } & Ya & Tidak \\
\hline 1. & Keterlibatan juru masak profesional & 81,43 & 18,57 \\
2. & Penggunaan teknologi & 94,29 & 5,71 \\
3. & Membuat menu baru secara rutin (continue) & 41,43 & 58,57 \\
4. & Menggunakan kandungan makanan lokal & 34,29 & 65,71 \\
5. & Konsumen mendapatkan pengalaman kuliner & 37,14 & 62,86 \\
\hline Sumber: Hasil Survei (2019) & &
\end{tabular}


Bentuk usaha dalam menciptakan kreativitas usaha dalam subsektor kuliner penting dilakukan disebabkan para penggiat sektor ekonomi kreatif di subsektor ini sadar bahwa usaha kuliner di Kota Samarinda berkembang sangat pesat dan masih banyak peluang walaupun banyak persaingan dari sesama penggiat kuliner yang memiliki variasi dan rasa yang khas dalam setiap kulinernya.

Berdasarkan jumlah sampel sebanyak 303 penggiat sector ekonomi kreatif subsektor kuliner di Kota Samarinda, peneliti melakukan pengelompokan kembali berdasarkan unsur kreativitas sehingga disimpulkan bahwa terdapat 23 usaha yang memiliki lebih banyak kreativitas dibandingkan dengan usaha yang lain. Hal ini dikarenakan ke-23 usaha tersebut telah menyediakan makanan lokal sebagai menunya antara lain Soto Banjar, Gado-Gado Banjar, Sambal Gami, Nasi Kuning Iwak Haruan, Lontong Sayur, Kepiting Soka, Pepes Kepiting Rajungan, Ayam Goreng Banjar, Bubur Ayam Samarinda, Mandai, Pizza Durian, Untuk-Untuk, Ote-Ote, dan Sayur Keladi.

Selanjutnya dari segi tempat ke-23 usaha kuliner tersebut memiliki tempat yang unik serta memberikan kesan yang nyaman untuk pembeli seperti gazebo dengan kolam ikan, resto dengan nuansa desa, resto dengan taman duduk dan lesehan, resto bernuansa kayu, resto yang dilengkapi dengan permainan seperti UNO dan bridge, resto dengan nuansa jawa, resto dengan nuansa Jepang dan resto dengan konsep grill. Selebihnya adalah resto dengan spot-spot fotografi yang unik.

Struktur pada sektor ekonomi kreatif subsektor kuliner di Kota Samarinda terlihat pada unsur unit usahanya. Pada model bisnis subsektor kuliner terdiri dari tiga kategori yaitu independent, chain dan franchise (Lazuardi \& Triady, 2015). Berdasarkan data yang telah terhimpun, sebanyak 60 persen model bisnis usaha kuliner di Kota Samarinda adalah independent. Model bisnis independent adalah model bisnis yang pengelolaannya dilakukan secara mandiri dan hanya dibuka pada satu daerah tertentu oleh pemilik usaha. Setelah itu diikuti oleh model bisnis chain sebesar 30 persen dan model bisnis franchise sebesar 10 persen. Model bisnis chain adalah model bisnis yang kepemilikannya oleh satu nama atau merek tetapi telah membuka cabang di beberapa tempat dengan standar pengelolaan yang sama. Model bisnis franchise serupa dengan model bisnis chain, perbedaannya adalah pada model bisnis franchise kepemilikan setiap cabang berbeda disebabkan pemilik usaha telah menjual mereknya ke pihak lain. Beberapa pemilik usaha kuliner yang memiliki model bisnis independent pada dasarnya dapat mengembangkan usahanya menjadi model bisnis chain agar penjualannya meningkat. Akan tetapi hal ini tidak dilakukan karena kondisi perekonomian yang sulit, kurangnya permodalan dan sewa tempat yang mahal.

Perilaku (Conduct) pada ekonomi kreatif subsektor kuliner di Kota Samarinda dapat dilihat dari sisi penentuan harga dan pemasarannya. Penentuan harga yang dilakukan oleh penggiat ekonomi kreatif subsektor kuliner sebanyak 60 persen menyatakan menetapkan sendiri dan sisanya sebanyak 40 persen menyatakan menetapkan setelah melihat informasi harga pesaing.

Selanjutnya dalam usaha pemasarannya, para penggiat subsektor kuliner menempuh berbagai cara untuk menarik konsumen. Pada tabel 3 dapat dilihat bahwa penggiat kuliner di Kota Samarinda mayoritas memilih pemasaran melalui Media Sosial sebanyak 91,43 persen diikuti oleh pemasaran melalui Aplikasi Online sebanyak 90 persen dan pemasaran getok tular (mulut ke mulut) sebanyak 67,14 persen. Hal ini mengindikasikan bahwa penggiat kuliner di Kota Samarinda telah dapat mengaplikasikan teknologi dengan baik pada kegiatan kuliner mereka. 
Tabel 3.

Strategi Pemasaran Sektor Ekonomi Kreatif Subsektor Kuliner Di Kota Samarinda Tahun 2019 (persen)

\begin{tabular}{llcc}
\hline No. & \multicolumn{1}{c}{ Pemasaran Produk } & Ya & Tidak \\
\hline 1. & Getok Tular & 67,14 & 32,86 \\
2. & Media sosial & 91,43 & 8,57 \\
3. & Aplikasi online & 90,00 & 10,00 \\
4. & Menjadi sponsor kegiatan & 4,29 & 95,71 \\
5. & Pamflet & 10,00 & 90,00 \\
6. & Website & 4,29 & 95,71 \\
\hline
\end{tabular}

Sumber : Hasil Survei (2019)

Kinerja (Performance) pada sektor ekonomi kreatif subsektor kuliner di Kota Samarinda dapat terlihat dari unsur omset yang dapat diraup dalam satu bulan dan penyerapan/penggunaan tenaga kerja. Hasil survei terhadap responden mengenai omset perbulan terlihat pada tabel 4 . Pada tabel 4 menunjukkan bahwa subsektor kuliner di Kota Samarinda mayoritas memiliki omset perbulan antara Rp. 10.000.000 - Rp. 49.999.999 yaitu sebesar 71,43 persen diikuti oleh sektor kuliner beromset lebih dari Rp. 50.000 .000 sebesar 17,14 persen.

Tabel 4.

Omset Sektor Ekonomi Kreatif Subsektor Kuliner di Kota Samarinda Tahun 2019 (persen)

\begin{tabular}{clc}
\hline No. & \multicolumn{1}{c}{ Jumlah Omset Perbulan } & Jumlah \\
\hline 1. & $<$ Rp. 5.000.000 & 7,14 \\
2. & Rp. 5.000.000 - Rp. 9.999.999 & 4,29 \\
3. & Rp. 10.000.000 - Rp. 49.999.999 & 71,43 \\
4. & $>$ Rp. 50.000.000 & 17,14 \\
\hline & \multicolumn{1}{c}{ Total }
\end{tabular}

Sumber: Hasil Survei (2019)

Meningkatnya omset pada subsektor kuliner akan berdampak pada penyerapan/penggunaan tenaga kerja. Berdasarkan hasil survei sampel, 55,71 persen subsektor kuliner di Kota Samarinda telah memiliki tenaga kerja 5-19 orang dan 35,71 persen memiliki tenaga kerja sebanyak 1-4 orang. Berdasarkan kuantitas/jumlah tenaga kerja, Badan Pusat Statistik Indonesia mengkategorikan skala usaha mikro dengan tenaga kerja 1-4 orang, usaha kecil memiliki jumlah tenaga kerja 5-19 orang, dan usaha menengah memiliki tenaga kerja 2099 orang. Oleh karena itu, berdasarkan kategori BPS dapat ditarik kesimpulan bahwa sebagian besar subsektor kuliner di Kota Samarinda ini termasuk usaha kecil.

\section{Potensi Sektor Ekonomi Kreatif Subsektor Kuliner Terhadap Pendapatan Asli Daerah di Kota Samarinda}

Pada kajian ini dilakukan analisis regresi linier sederhana dimana variabel penelitian terbagi menjadi dua yaitu variabel dependen $(Y)$ dan variabel independen $(X)$. Variabel dependen pada penelitian ini adalah realisasi pajak restoran, sedangkan variabel independen pada penelitian ini adalah jumlah wajib pajak.

Setelah dilakukan analisis regresi linier sederhana dengan SPSS seperti pada Tabel 5, maka dilakukan uji asumsi klasik, Adapun uji asumsi klasik yang dilakukan antara lain sebagai berikut: 
a) Uji Heterskedastisitas

Diperoleh $p$-value uji Heteroskedastisitas dengan uji Glejser sebesar 0,003 seperti pada Tabel 5, dimana $p$-value kurang dari taraf signifikansi yaitu 5\% atau 0,05 sehingga dapat disimpulkan bahwa terjadi heteroskedastisitas pada model regresi.

Tabel 5.

Uji Glejser

\begin{tabular}{|c|c|c|c|c|c|c|}
\hline \multicolumn{7}{|c|}{ Coefficients $^{\mathbf{a}}$} \\
\hline \multirow[b]{2}{*}{ Model } & & \multicolumn{2}{|c|}{ Unstandardized Coefficients } & \multirow{2}{*}{$\begin{array}{c}\begin{array}{c}\text { Standardized } \\
\text { Coefficients }\end{array} \\
\text { Beta } \\
\end{array}$} & \multirow[b]{2}{*}{ t } & \multirow[b]{2}{*}{ Sig. } \\
\hline & & $\mathrm{B}$ & Std. Error & & & \\
\hline 1 & (Constant) & -262892611 & 206116102.9 & & -1.275 & .209 \\
\hline & WajibPajak & 2666420.316 & 853.755 .057 & .418 & 3.123 & .003 \\
\hline
\end{tabular}

a. DependentVariable: Abs_RES

b) Uji Autokorelasi

Pada Tabel 6, diperoleh $p$-value uji Autokorelasi dengan uji Run sebesar 0,013, dimana $p$-value kurang dari taraf signifikansi yaitu 5\% atau 0,05 sehingga dapat disimpulkan bahwa terjadi autokorelasi pada model regresi.

Tabel 6.

Uji Run

\begin{tabular}{|l|r|}
\hline \multicolumn{2}{|c|}{ Runs Test } \\
\hline & $\begin{array}{c}\text { Unstandardized } \\
\text { Residual }\end{array}$ \\
\hline Test Value $^{\mathrm{a}}$ & -80742634.5 \\
\hline Cases < Test Value & 24 \\
\hline Cases > Test Value & 24 \\
\hline Total Cases & 48 \\
\hline Number of Runs & 16 \\
\hline Z & -2.480 \\
\hline Asump.Sig.(2-tailed) & .013 \\
\hline
\end{tabular}

a. Median

Karena kedua asumsi tidak terpenuhi, maka dilakukan pengujian ulang dengan pendekatan Weight Least Square untuk mengatasi permasalahan heteroskedastisitas terlebih dahulu.

a) Pendekatan Weight Least Square (WLS)

Setelah terindikasi terjadi heteroskedastisitas, maka dilakukan perbaikan pada model awal menggunakan metode WLS yaitu pembobotan data dengan satu faktor pengali atau pembobot yang tepat. Dalam pemilihan ini pembobotan yang diberikan yaitu $\frac{1}{\sqrt{X_{i}}}, \frac{1}{X_{i}}, \frac{1}{E\left(Y_{i}\right)}$, dan $\frac{1}{\sigma_{i}}$. Pembobotan dilakukan dengan menggunakan SPSS.

Dengan menggunakan SPSS, diketahui bahwa dari semua pembobotan yang dilakukan hanya satu pembobot saja yang terpilih yaitu pembobot $\frac{1}{\sigma_{i}}$ dimana dalam prosedurnya, nilai $\frac{1}{\sigma_{i}}$ dikalikan terhadap semua variabel dan kemudian hasilnya diregresikan kembali. Variabel realisasi pajak restoran selanjutnya disimbolkan dengan Y_WLS sedangkan 
variabel jumlah wajib pajak selanjutnya disimbolkan dengan X_WLS. Seperti pada tabel 7 dibawah ini.

Tabel 7.

Uji Glejser Setelah Pembobotan dengan $\frac{1}{\sigma_{i}}$

\begin{tabular}{|c|c|c|c|c|c|c|}
\hline \multicolumn{7}{|c|}{ Coefficients $^{\mathrm{a}}$} \\
\hline \multirow[b]{2}{*}{ Model } & & \multicolumn{2}{|c|}{$\begin{array}{l}\text { Unstandardized } \\
\text { Coefficients }\end{array}$} & \multirow{2}{*}{$\begin{array}{c}\begin{array}{c}\text { Standardized } \\
\text { Coefficients }\end{array} \\
\text { Beta } \\
\end{array}$} & \multirow[b]{2}{*}{$\mathrm{t}$} & \multirow[b]{2}{*}{ Sig. } \\
\hline & & $\mathrm{B}$ & Std. Error & & & \\
\hline 1 & (Constant) & $7.120 \mathrm{E}-9$ & .000 & & 6.060 & .000 \\
\hline & X_WLS & 7259.828 & 8606.181 & .123 & .844 & .403 \\
\hline
\end{tabular}

a. DependentVariable: Abs_RES2

Pada tahap ini diperoleh $p$-value uji Glejser sebesar 0,403 seperti pada Tabel 7, dimana nilai $p$-value lebih besar dari taraf signifikansi yaitu $5 \%$ atau 0,05 . Sehingga dapat disimpulkan bahwa tidak terjadi heteroskedastisitas pada model regresi.

Untuk menguji nilai regresinya maka dilakukan Uji Determinasi dan Uji Parsial ( $t$ ) yang tersaji dibawah ini.

a) Koefisien Determinasi

Berdasarkan Tabel 8 diperoleh nilai koefisien determinasi sebesar 1 yang menyatakan bahwa 100\% variasi yang terjadi pada realisasi pajak restoran di Samarinda tahun 2015 hingga 2018 disebabkan oleh jumlah wajib pajak. Koefisien determinasi sama dengan 1 atau $100 \%$ menandakan bahwa realisasi pajak restoran di Samarinda dapat ditafsirkan oleh jumlah wajib pajak secara sempurna.

Tabel 8.

Koefisien Determinasi

\begin{tabular}{|c|r|r|r|r|}
\multicolumn{5}{|c}{ Model Summary } \\
\hline Model & $\mathrm{R}$ & R Square & $\begin{array}{c}\text { Adjusted R } \\
\text { Square }\end{array}$ & $\begin{array}{c}\text { Std. Error of } \\
\text { the Estimate }\end{array}$ \\
\hline 1 & $1.000 \mathrm{a}$ & 1.000 & 1.000 & .00000 \\
\hline
\end{tabular}

a. Predictors:(Constant), X_WLS

b) Uji Parsial

Uji parsial bertujuan untuk mengetahui apakah variabel independen $(X)$ secara parsial (masing-masing variabel) berpengaruh terhadap variabel dependen $(Y)$. Berdasarkan uji yang telah dilakukan dengan SPSS pada Tabel 9 di peroleh $p$-value sebesar 0,000 lebih kecil dari taraf signifikansi yaitu $5 \%$ atau 0,05 . Sehingga dapat disimpulkan bahwa jumlah wajib pajak berpengaruh terhadap realisasi pajak restoran Kota Samarinda.

Tabel 9.

Uji Parsial

Coefficients $^{\mathbf{a}}$

\begin{tabular}{|c|c|c|c|c|c|c|}
\hline \multirow{2}{*}{\multicolumn{2}{|c|}{ Model }} & \multicolumn{2}{|c|}{ Unstandardized Coefficients } & \multirow{2}{*}{$\begin{array}{c}\text { Standardized } \\
\text { Coefficients } \\
\text { Beta } \\
\end{array}$} & \multirow[b]{2}{*}{$\mathrm{t}$} & \multirow[b]{2}{*}{ Sig. } \\
\hline & & $\mathrm{B}$ & Std. Error & & & \\
\hline 1 & (Constant) & $-6.364 \mathrm{E}-9$ & .000 & & -3.903 & .000 \\
\hline & X_WLS & 15686484.90 & 11943.549 & 1.000 & 1313.386 & .000 \\
\hline
\end{tabular}

a. DependentVariable: Y_WLS 
Setelah semua uji terpenuhi maka dilakukan estimasi parameter pada data dengan variable X_WLS sebagai variabel independen (jumlah wajib pajak restoran) dan variabel Y_WLS se-bagai variabel independen (nilai realisasi pajak restoran) yang tersaji pada Tabel 10 di bawah ini.

Tabel 10.

Estimasi Parameter

\begin{tabular}{|c|c|c|c|c|c|c|}
\hline \multicolumn{7}{|c|}{ Coefficients $^{\mathrm{a}}$} \\
\hline \multirow[b]{2}{*}{ Model } & & \multicolumn{2}{|c|}{ Unstandardized Coefficients } & $\begin{array}{l}\text { Standardized } \\
\text { Coefficients }\end{array}$ & \multirow[b]{2}{*}{$\mathrm{t}$} & \multirow[b]{2}{*}{ Sig. } \\
\hline & & B & Std. Error & Beta & & \\
\hline 1 & (Constant) & $-6.364 \mathrm{E}-9$ & .000 & & -3.903 & .000 \\
\hline & X_WLS & 15686484.90 & 11943.549 & 1.000 & 1313.386 & .000 \\
\hline
\end{tabular}

a. DependentVariable: Y_WLS

Berdasarkan pengujian dengan SPSS pada Tabel 10 diperoleh nilai estimasi untuk parameter $\beta_{0}$ adalah $-0,000000006364$ dan nilai estimasi untuk parameter $\beta_{1}$ adalah $15.686 .484,90 \approx 15.686 .485$ sehingga diperoleh estimasi model regresi sebagai berikut :

$$
\widehat{Y}=-0.000000006364+15,686,485 X
$$

Berdasarkan model tersebut dapat diketahui bahwa konstanta sebesar 0,000000006364 menyatakan bahwa tanpa dipengaruhi oleh jumlah wajib pajak maka realisasi pajak restoran Kota Samarinda adalah sebesar Rp. 0,000000006364, -. Hal ini dikarenakan jumlah wajib pajak memiliki pengaruh yang tinggi pada realisasi pajak restoran Kota Samarinda, sehingga apabila terdapat faktor lain yang ditaksir mampu mempengaruhi realisasi pajak restoran Kota Samarinda, pengaruhnya tidak akan sebesar jumlah wajib pajak.

Sedangkan koefisien regresi sebesar 15.686 .485 untuk variabel $(X)$ yaitu jumlah wajib pajak menyatakan bahwa setiap penambahan 1 jumlah wajib pajak akan meningkatkan realisasi pajak restoran Kota Samarinda sebesar Rp. 15.686.485, -.

Setelah estimasi dilakukan maka dilakukan uji asumsi klasik ulang agar estimasi yang dilakukan memperoleh model regresi yang menghasilkan estimator linier tidak bias yang terbaik (Best Linier Unbiased Estimator/BLUE).

Terdapat tiga asumsi dalam analisis regresi linier sederhana, antara lain uji heteroskedastisitas, autokorelasi dan normalitas residual yang tersaji di bawah ini, yaitu:

a) Uji heteroskedastisitas

Berdasarkan Tabel 11 dapat diketahui bahwa p-value uji Glejser sebesar 0,403 lebih besar dari taraf signifikansi yaitu $5 \%$ atau 0,05 . Sehingga dapat disimpulkan bahwa tidak terjadi heteroskedastisitas pada model regresi.

Tabel 11.

Uji Glejser

\begin{tabular}{|c|c|c|c|c|c|c|}
\hline \multicolumn{7}{|c|}{ Coefficients $^{\mathrm{a}}$} \\
\hline \multirow[b]{2}{*}{ Model } & & \multicolumn{2}{|c|}{ Unstandardized Coefficients } & $\begin{array}{l}\text { Standardized } \\
\text { Coefficients }\end{array}$ & \multirow[b]{2}{*}{$\mathrm{t}$} & \multirow[b]{2}{*}{ Sig. } \\
\hline & & $\mathrm{B}$ & Std. Error & Beta & & \\
\hline 1 & (Constant) & $7.120 \mathrm{E}-9$ & .000 & & 6.060 & .000 \\
\hline & X_WLS & 7259.828 & 8606.181 & .123 & .844 & .403 \\
\hline
\end{tabular}

a. DependentVariable: Abs_RES2 
b) Uji Autokorelasi

Berdasarkan Tabel 12 dapat diketahui bahwa p-value uji Run sebesar 0,109 lebih besar dari taraf signifikansi yaitu 5\% atau 0,05. Sehingga dapat disimpulkan bahwa tidak terjadi autokorelasi pada model regresi.

Tabel 12 .

Uji Run

\begin{tabular}{|l|r|}
\multicolumn{2}{|c}{ Runs Test } \\
\hline & $\begin{array}{c}\text { Unstandardized } \\
\text { Residual }\end{array}$ \\
\hline Test Valuea & .00000 \\
\hline Cases < Test Value & 24 \\
\hline Cases > = Test Value & 24 \\
\hline Total Cases & 48 \\
\hline Number of Runs & 19 \\
\hline Z & -1.605 \\
\hline Asump.Sig.(2-tailed) & .109 \\
\hline
\end{tabular}

a. Median

c) Uji Normalitas

Berdasarkan Tabel 13 dapat diketahui bahwa p-value uji Kolmogorov-Smirnov sebesar 0.000 lebih kecil dari taraf signifikansi yaitu $5 \%$ atau 0,05 . Sehingga dapat disimpulkan bahwa data residual tidak berdistribusi normal. Hal ini dikarenakan jumlah sampel yang masih tergolong sedikit.

Tabel 13.

Uji Kolmogorov-Smirnov

One-Sample Kolmogorov-Smirnov Test

\begin{tabular}{|ll|r|}
\hline & \multicolumn{2}{c|}{$\begin{array}{c}\text { Unstandardized } \\
\text { Residual }\end{array}$} \\
\hline $\mathrm{N}$ & & 48 \\
Normal Parameters & Mean & .0000000 \\
Most Extreme & Std. Deviation & .00000001 \\
Differences & Absolute & .194 \\
& Positive & .158 \\
& Negative & -.194 \\
Test Statistic & & .194 \\
Asymp.Sig.(2-tailed) & & $.000^{\mathrm{c}}$ \\
\hline
\end{tabular}

a. Test distribution is Normal.

b. Calculated from data.

c. Lilliefors Significance Correction

Berdasarkan estimasi model regresi, diketahui bahwa setiap penambahan 1 jumlah wajib pajak akan meningkatkan realisasi pajak restoran Kota Samarinda sebesar Rp.15.686.485,-Dalam hal ini, disimulasikan realisasi pajak restoran yang ingin dicapai adalah Rp. 5.000.000.000,- (5 Miliar Rupiah) dan ingin diketahui berapa jumlah wajib pajak yang 
diperlukan. Apabila realisasi pajak restoran Kota Samarinda sebesar Rp. 15.686.485,- diperoleh dari penambahan 1 jumlah wajib pajak, maka:

$$
\frac{5,000,000,000}{15,686,485}=318.75 \approx 319
$$

untuk realisasi pajak restoran Kota Samarinda sebesar Rp. 5.000.000.000, - membutuhkan jumlah wajib pajak sebanyak 319 .

\section{KESIMPULAN}

Adapun kesimpulan dari kajian Analisis Potensi dan Pemetaan Sektor Ekonomi Kreatif Subsektor Kuliner Terhadap Pendapatan Asli Daerah di Kota Samarinda adalah sebagai berikut (1) Hasil identifikasi kreativitas dan karakteristik sektor ekonomi kreatif subsektor kuliner di Kota Samarinda yaitu (a) Dari identifikasi kreativitas, unsur keterlibatan juru masak profesional dan unsur penggunaan teknologi yang persentasenya diatas 50 persen; (b) Berdasarkan Struktur, unit usaha subsektor kuliner di Kota Samarinda masih bersifat independen; (c) Berdasarkan Perilaku, terlihat pada unsur penentuan harga yang mayoritas menetapkan harga sendiri (self pricing) tanpa melihat informasi harga dari penggiat kuliner lain serta metode pemasarannya masih menggunakan cara pemasaran dari Media Sosial, Mulut ke Mulut dan Aplikasi Online; (d) Berdasarkan Kinerja, terlihat dari unsur omset dan tenaga kerja yang mayoritas masih berskala usaha kecil.

Potensi subsektor kuliner terhadap pendapatan asli daerah berdasarkan model perhitungan potensi pajak restoran di Kota Samarinda, diperoleh kesimpulan setiap penambahan 1 jumlah wajib pajak subsektor kuliner akan meningkatkan realisasi pajak restoran Kota Samarinda sebesar rata-rata Rp. 15.686.485,- asumsi ceteris paribus.

\section{REKOMENDASI}

Adapun rekomendasi dari kajian Analisis Potensi dan Pemetaan Sektor Ekonomi Kreatif Subsektor Kuliner Terhadap Pendapatan Asli Daerah di Kota Samarinda yaitu : (1) Kuliner lokal Kota Samarinda dapat dilakukan kreativitas dan dibuat dengan sentuhan khas tradisional maupun modern untuk penyajiannya. Kreatifitas subsektor kuliner di Kota Samarinda sudah selayaknya semakin kreatif dengan memenuhi kategori kreatifitas dalam subsektor ini yaitu Membuat menu baru secara rutin, Menggunakan kandungan makanan lokal dan Konsumen mendapatkan pengalaman kuliner; (2) Pemerintah Kota Samarinda melalui instansi terkait dapat menciptakan wadah khusus kuliner yang bersifat tetap yang disertai dengan penyelenggaraan event besar; (3) Meningkatkan pelatihan dan pembinaan bagi penggiat usaha kuliner; (4) Pemerintah Kota Samarinda melakukan sinergi dengan penggiat usaha kuliner dan agen wisata dengan membuat rujukan untuk wisatawan yang berkunjung ke Kota Samarinda; (5) Untuk meningkatkan pajak restoran, Pemerintah Kota Samarinda melalui instansi terkait segera melakukan pengenaan pajak restoran (PB1) yang merata kepada semua penggiat kuliner. Selain itu pengelolaan data wajib pajak restoran harus lengkap, mutakhir, andal dan akurat.

\section{UCAPAN TERIMA KASIH}

Ucapan terima kasih disampaikan kepada Badan Pendapatan Daerah Kota Samarinda, Dinas Koperasi dan UKM Kota Samarinda dan Dinas Pariwisata Kota Samarinda serta semua pihak yang telah berperan dalam penulisan kajian ini.

\section{DAFTAR PUSTAKA}

Hennekam, S., \& Bennett, D. (2017). Creative industries work across multiple contexts: 
common themes and challenges. Personnel Review, 46(1), 68-85. https://doi.org/10.1108/PR-08-2015-0220.

Howkins, J. (2002). The creative economy: How people make money from ideas. Penguin UK. http://xa.yimg.com/kq/groups/22416650/836839594/name/RetirementAgevsLifeSpan1121.pd f.

Indonesia, D. P. R. (2008). Pengembangan ekonomi kreatif Indonesia 2025. Jakarta: Kementerian Perdagangan RI.

Kerlinger, F. N. (2006). Asas-asas Penelitian Behavioral (edisi ketiga). Yogyakarta: UGM Press. xiii.Umar, H. 1997. Metodologi Penelitian : Aplikasi dalam pemasaran. Jakarta: PT Gramedia.

Lazuardi, M., \& Triady, M. S. (2015). Ekonomi Kreatif: Rencana pengembangan kuliner nasional 2015-2019. Jakarta: PT. Republik Solusi.

Mellita, D. (2014). Pemetaan industri kreatif dalam meningkatkan pertumbuhan ekonomi kawasan urban di kota Palembang.

Moleong, L. J. (2005). Metodologi kualitatif. Edisi Revisi. Bandung: PT Remaja Rosdakarya.Lin, S. 2002. Optimum Strategies for Creativity and Longevity. Diakses pada 6 Juni 2019 dari

Statistik, B. P. (2018). Publikasi Ekonomi Kreatif. Jakarta: Statistics Indonesia.

Sugiyono, P. (2001). Metode Penelitian Administrasi (edisi ke-3). Jakarta: Alfabeta.

Todaro, M. P., \& Smith, S. C. (2006). Pembangunan Ekonomi Jilid 1 Edisi Kesembilan. Erlangga. Jakarta.Jakarta: Erlangga. 